\title{
ANGLO-AMERICAN CONCEPTIONS OF PROFESSIONAL RESPONSIBILITYAND THE REFORM OF JAPANESE LEGAL EDUCATION: CREATING A VIRTUOUS CIRCLE?
}

\author{
By KIM ECONOMIDES
}

IN THIS article I describe how ethics and the professional responsibilities of lawyers have become increasingly prominent in debates on the future of mainstream legal education in Anglo-American and other common law jurisdictions. How are these debates in the West impacting on the current reform of Japanese legal education and, vice versa, could these reforms influence developments here? My observations build on those made during a previous visit to Japan when I delivered a lecture on ethical legal education. ${ }^{1}$ Now, a decade on, I am encouraged to see that real progress is being made with widening participation and the implementation of liberalising reforms designed not only to introduce an ethical perspective into the training of modern Japanese lawyers but that other educational models, including clinical legal education and developments in simulation-based learning, are also under active consideration by Japanese reformers. ${ }^{2}$ Yet it is with some irony that virtual learning environments (VLEs) recently developed in the UK, but modeled on Japanese computer games technology, are being re-cycled and exported back to Japan along with ethical perspectives that are such an ingrained part of traditional Japanese legal consciousness $\left(\right.$ ho-ishiki) ${ }^{3}$ and social responsibility. If Japanese reformers feel they may have something to learn from foreign adaptations of their indigenous homegrown practices might it also be true that reformers here could learn from latest Japanese developments, thus creating a virtuous circle? I review these converging trends that confirm my belief that ethical perspectives very soon will become, if indeed they have not done so already, part of a global "new core" centered on legal ethics that lies at the heart of modern legal education and practice.

- Professor of Legal Ethics, School of Law, University of Exeter, UK. This is a revised version of a keynote address delivered in March 2005 at the Osaka International Conference Centre to a conference organised by the Kwansei Gakuin University Committee for the Promotion of Educational Innovation in Law Schools and sponsored by Kangaku and the Japanese Ministry of Education, Science and Technology. Apart from thanking these sponsors I wish also to acknowledge the valuable contributions of two anonymous reviewers and the conference participants whose discussions are fully recorded in S. Brown et al (eds) Can Justice be Taught? Social Responsibility and Law School Education, Kwansei Gakuin University Press, 2006 [in Japanese], and reported in S. Brown, (2005) "A True Meeting of Minds: A Conference Report from Japan”, Vol.8:1 Legal Ethics, pp. 12-15.

${ }^{1}$ K. Economides, (1997) "Educating Lawyers for the New Millennium - the Ethical Dimension", Vol.31: 3 Comparative Law Review, pp.157-174. The Canon Foundation Lecture sponsored by the Canon Foundation and delivered to the Institute of Comparative Law at Chuo University, Tokyo, April 1997. See also E. Chen, (1989) "The National Law Examination of Japan" Vol.39 Jor of Legal Education pp.4-21; E. Feldman, (1993) "Mirroring Minds: Recruitment and Promotion in Japan's Law Faculties" Vol.41 American Jor. of Comparative Law pp.466-474.

${ }^{2}$ Eg., P. McKellar and P.Maharg, (2005) "Virtual learning Environments: The alternative to the Box under the Bed", The Law Teacher, Vol. 39:1, pp.43-56.

${ }^{3}$ T. Kawashima, "Dispute Resolution in Contemporary Japan" in A.T.von Mehren (ed) Law in Japan: The Legal Order of a Changing Society Tokyo, Harvard University Press \& Tuttle, 1964. See also S. Miyazawa, (1987) "Taking Kawashima Seriously: A Review of Japanese Research on Japanese Legal Consciousness and Disputing Behavior" Vol.21:2 Law \& Society Rev., pp.219-241; D. F. Henderson, Conciliation and Japanese Law: Tokugawa and Modern Tokyo, University of Tokyo Press, 19652 Vols 


\section{The Fall and Rise of Ethics in Western Legal Education}

Ethics and the professional responsibility of lawyers has become an increasingly prominent theme in Anglo-American legal education over the past two decades. On both sides of the Atlantic there has been growing interest in "the law of lawyering" and an awareness of the need and possibility of teaching ethics to future lawyers. ${ }^{4}$ Following Watergate, the ethical responsibilities of legal professionals has become relatively well established - even if not necessarily well-taught - in the United States and, more recently, in the United Kingdom serious efforts have been made to provide a foundation for the academic study of professional legal ethics. ${ }^{5}$ Over the past decade the United Kingdom has seen a small group of law teachers challenge dominant positivistic approaches that for generations has excluded serious academic analysis of lawyers' ethics. ${ }^{6}$ The aim of this group has been to try to persuade all stakeholders with an interest in legal education to accept that meaningful ethical discussion can and should feature more prominently in contemporary legal education. Some have suggested that for law schools to continue to fail to prepare their students for the ethical dilemmas they will inevitably confront in the early years of practice is tantamount to a failure of their own professional responsibility as teachers. ${ }^{7}$ But the debate on the ethical content of legal education touches all stages of the educational continuum relevant to the formation of professional character ranging from the introduction of citizenship (including human rights law) in the national school curriculum ${ }^{8}$, to the undergraduate law degree, through to the vocational stage of legal education and finally continuing professional development.'

4.

See K. Economides (1999), "Learning the Law of Lawyering", Current Legal Problems 1999,Vol.52, ed M.D.A.Freeman, Oxford, OUP, pp. 392-418.

${ }^{5}$.See K. Economides (1999), "Learning the Law of Lawyering", Current Legal Problems 1999,Vol.52, ed M.D.A.Freeman, Oxford, OUP, pp. 392-418.

See, eg, D.L.Rhode (1995) "Into the Valley of Ethics: Professional Responsibility and Educational Reform" Vol. 58 Law and Contemporary Problems p. 139. In 1998 an international journal Legal Ethics was launched in the UK. See also K. Economides (ed.), Ethical Challenges to Legal Education and Conduct, Oxford, Hart.1998, chap. 11.

${ }^{6}$ For an excellent recent review see D. Nicolson (2005) "Making Lawyers Moral? Ethical Codes and Moral Character" Vol. 25:4 Legal Studies, pp. 601-626.

7 See K. Economides and J. Webb (2000) "Do Law Schools Care About Law Students and Legal Values?” Vol.3:1 Legal Ethics, pp.1-9.

${ }^{8}$ See activities of the Public Legal Education Group set up by the Citizenship Foundation and the Civil Justice Council to promote awareness of the legal system amongst young people. Two projects are under way: "The first involves the development of a pilot scheme matching individual volunteer lawyers with schools to assist in supporting teachers in delivering the Citizenship programme to young people. Anecdotal evidence shows that in some areas, teaching staff may need support from the legal industry to provide a more effective experience for young people. Urban and rural schools will be involved and the scheme will be evaluated by the Citizenship Foundation for its effectiveness and benefit to teachers, schools and the young people concerned. The second project that is longer term involves collating of the existing research regarding the need for a cohesive programme of public legal education in England and Wales, and an umbrella organisation to oversee the direction of such a programme. It is envisaged that any system of public legal education would not be limited to young people, but would seek to include people of all ages and backgrounds, and would be aimed at promoting inclusion in society and greater understanding of civil legal issues affecting the population." See further: http://www.civiljusticecouncil.gov.uk/493.htm

${ }^{9}$ See work of the Ethics Education Forum that was set up by the Law Society in 2004 in the context of a major review of vocational training - the Training Framework Review (TFR) - to inform policy on how ethics should be introduced throughout the educational continuum. See J. Webb and A. Fancourt, (2004) "The Law Society's Training Framework Review: On the Straight and Narrow or Long and Winding Road?" Vol.38:3 Law Teacher, pp. 293-325, at p.310-11 
The ethical dimension has also surfaced in other common law jurisdictions beyond the AngloAmerican systems (notably New Zealand, Australia, Canada) that have already introduced ethics into their law curricula. ${ }^{10}$ New Zealand and Australian law schools are playing a leading role in examining the place of ethics in legal education and hosting international conferences that aim to carry these educational debates both further and deeper. ${ }^{11}$ Similar debates are getting under way in Latin America and other parts of Asia - eg the South Pacific, India, Korea and Taiwan - and so Japan is therefore by no means alone amongst Australasian countries in thinking about the ethical dimension to modern legal education. ${ }^{12}$ And this issue is also attracting increasing attention in the civil law systems throughout Europe and also at the transnational level of EU law. ${ }^{13}$ Although legal ethics are now coming of age it would be wrong to think that this topic has only recently been discovered; in fact it would be far more accurate to say that legal ethics has been 're-discovered'.

It is therefore important to place this current trend in an historical as well as global context. One might be forgiven for thinking that legal ethics is a recent discovery, and in a sense it is, but it also to be found at the root of the western legal tradition. ${ }^{14}$ The question "Can Justice be Taught?" is of course profoundly philosophical and one that was also asked by the Ancient Greeks. ${ }^{15}$ It is worth recalling the origins of western legal education in which law and morals were fused within an oral tradition and that legal education, in any systematic sense, is a relatively recent phenomenon. In ancient Greece and Rome there existed some formal training in advocacy (moral and legal) supporting the establishment of a professional class of persons with legal expertise but this class was not a profession as such and early forms of legal education were delivered primarily through observation and training acquired by serving as an apprentice to a legal consultant (jurisprudent) rather than through formal academic study. Prior to law reporting legal texts were for many centuries quite rare, which meant that the art of rhetoric inevitably formed the 'core' of early legal education. Gradually, however, as texts on both law and custom became more common, and records started to

\footnotetext{
${ }^{10}$ See D. Webb (2002) "Ethics as a Compulsory Element of Qualifying Law Degrees: Some Modest Expectations" Vol. 4:2 Legal Ethics, pp. 109-126 (on New Zealand); M. A. Noone and J. Dickson (2002) "Teaching Towards a New Professionalism: Challenging Law Students to Become Ethical Lawyers" Vol. 4:2 Legal Ethics, pp. 127-145 (on Australia). On recent Canadian developments that incorporate an economic perspective on legal ethics - or 'ethinomics' - see: R. Graham, Legal Ethics: Theories, Cases and Professional Regulation Toronto: Edmond Montgomery, 2004.

${ }^{11}$ See K. Economides and J. Webb (2002) "Teaching Ethics and Professionalism: A Lesson from the Antipodes" Vol.4:2 Legal Ethics, pp.91-94. For an accounts of the First International Conference on Lawyers' Ethics see: S. Nelson, (2004) "Reflections from the International Conference on Legal Ethics from Exeter" Vol.7 Legal Ethics, pp.159-166. A follow-up international Legal Ethics Colloquium was held in February 2005 at the University of Canterbury in Christchurch, New Zealand and the Second International Conference on Lawyers' Ethics met in Auckland, New Zealand in 2006. See L.Haller (2006) "Professional Ethics and Personal Integrity: Report from the International Conference on Legal Ethics, Auckland, New Zealand" Vol.9:1 Legal Ethics pp. 13-15. A third international conference on legal ethics will be held in 2008 on the Gold Coast, Australia.

12 See chapters on South Pacific and Brazil in Economides supra n.5. See also: H. Kim, (2002) "In Search of the 'Soul of Professionalism': The Case of Legal Education Reform Efforts in South Korea" Vol. 5 Legal Ethics, pp. 2733 (on South Korea); J. Gandhi (ed.) Power and Passion: Study of Socio-Ethical Concerns of the Lawyers (forthcoming, Gyan Publishing, Delhi, 2008) (on India); and Su-Po Kao (2004) "The Legal Profession as an Intermediary: A Framework on Lawyers in Society" Vol. 7:1 Legal Ethics, pp. $39-53$ (on Taiwan).

${ }^{13}$ See K. Raes \& B. Claessens (eds.) Towards a new Ethical Framework for a Legal Profession in Transition? Proceedings of the European conference on ethics and the legal profession, held at Ghent University (Belgium) on 25 and 26 October 2001 Intersentia, Antwerp, 2002.

${ }^{14}$ See H. J Berman, Law and Revolution. The Formation of the Western Legal Tradition, Cambridge, Harvard Univ. Press, 1983 and G. Piva and F. Spantigati (eds) Nuovi Moti Per La Formazione Del Diritto Padova, CEDAM, 1988.

${ }^{15}$.See C. Gill in Economides supra, n.5. See further See A. Gutman, Can Virtue be Taught?" (1993) 45 Stanford Law Rev., p. 1759
} 
be kept of court decisions, this dominant oral tradition was supplanted with a new written tradition created by full-time law teachers dedicated to establishing and communicating a literature on, about and for law.

Legal education started out by asking universal questions linking legal rules, morals and justice and only much later were these elements separated, with some discarded altogether. Early legalists were certainly not parochial in their outlook and did not draw sharp distinctions between law and morality, nor did they fail to consider the relationship with other professions and disciplines. If one draws a distinction between legal education and training it could be argued that with the passage of time the latter has steadily displaced the former with the result that the boundaries of legal thought have been shrinking and the legal mind has become more introverted and absorbed with technical ephemeral rules rather than fundamental values. Roman law, canon law and international law - the ius commune - was the focal point of legal study in the medieval universities on the continent of Europe and these legal sources formed the basis of a common transnational legal language facilitating trade between commercial classes. The English common law was an exception to this trend and although to some extent influenced by this ius commune its impact in England was greatly reduced by the early development of an indigenous and quite sophisticated legal culture relatively insulated from Roman law. ${ }^{16}$ Legal education in medieval England was provided by the Inns of Court that organised apprenticeships involving both shadowing practitioners and practical exercises - and of course dining - within a closed, and almost monastic, community. With the advent of printing, legal texts started to supplant, but not replace, these informal methods of socialisation. Organised legal education for solicitors did not commence until Sir William Blackstone started to deliver his famous lectures on English law at Oxford in the 1750s and it was not until the Victorian era, with visionaries such as John Austin, Jeremy Bentham and Sir Henry Maine, that university liberal legal education became established at University College London and beyond, including the Council of Legal Education which was set up in $1852 .{ }^{17}$ Bentham's legacy to the modern legal system was to open up the possibility of subjecting law to rational inquiry and he greatly facilitated the creation and establishment of a science of law. However, the moral foundations underpinning and informing his positivism can easily be overlooked. ${ }^{18}$

Two points are worth emphasising about the history and character of Anglo-American legal education in the context of ethical debates now taking place in Japanese law schools and elsewhere: there is nothing particularly new or original about either: a) linking law with morality; or b) offering practical training in legal rhetoric - or what today would be covered in activities labelled variously as 'advocacy', 'mooting' or 'clinical legal education' - for each approach has been present if not always visible within western legal education since its inception even though subsequently both practices have enjoyed a chequered history and, in more recent times, are often absent from the formal and positivistic training in 'legal science' offered by mainstream curricula found in the majority of modern law schools. ${ }^{19}$

\footnotetext{
${ }^{16}$ See R.C. van Caenegem, The Birth of the English Common Law (Cambridge, CUP, 1973)

${ }^{17}$ See R. Cocks, Foundations of the Modern Bar London, Sweet \& Maxwell,1983 and Sir Henry Maine : a study in Victorian jurisprudence Cambridge, CUP, 1988.

${ }^{18}$ L. Campos Boralevi, Bentham and the Oppressed Berlin, 1984). On the ethical foundations of positivism see, T. Campbell, The Legal Theory of Ethical Positivism Aldershot, 1996); N. MacCormick (1989)‘The Ethics of Legalism’ Vol. 2 Ratio Juris 184.

${ }^{19}$ It is worth noting that some clinical legal educators perceive clinical legal education as having wider functions, especially given the increasing diversity of models of clinical legal education with the potential inclusion of activities such as Innocence Projects, law reform projects and Street Law clinics alongside more 'traditional' advice and/or representation clinics.
} 


\section{The Poverty of Contemporary (Positivistic) Legal Education}

While it may well be true that legal education has certain shortcomings when it comes to communicating a deep sense of professional responsibility to future members of the legal profession it must be recognised that this is not the only, or even the primary, reason for exploring the ethical dimension to legal practice within law schools. The driving force behind much current reform effort common across many jurisdictions and professions, particularly when led by professional associations, is adverse public reaction to professionals who may no longer be seen as trustworthy. Ethics may be viewed as a means to boost the public image of lawyers whose standing may have been undermined by the ubiquitous lawyer joke and statistics revealing increasing numbers of lawyer complaints and defalcations. The case for educational reform has more to do with making lawyers 'good' in a moral sense rather than technically competent in the handling (or manipulation) of legal rules; and as law teachers our aim should be to develop and reinforce understanding of the public and professional role of the lawyer in a modern society that reaches beyond the immediate obligations owed to the private client. ${ }^{20}$ Lawyers everywhere - whether in public or private practice, rural or global corporate law firms - need a better balanced, mature and more responsible approach to their professional duties and a better understanding of how these duties connect (or conflict) with their private morality.

A central mission of the modern law school must therefore be to create good lawyers capable of carrying out what Damon has called "good work". ${ }^{21}$ A key decision for any law school is how to identify, construct and promote its own particular conception of the 'good lawyer' from amongst the many competing conceptions that are available and to make explicit the underlying ethical, moral and legal values it seeks to promote. Ethics are of course already present in the formal and informal law curriculum but are not always made explicit. It is therefore arguable that law teachers have a responsibility to help their students see the various applications of the skills that are imparted to them and to help them make informed choices about where, for whom and how they will practice law in the future. ${ }^{22}$ Sadly this does not yet seem to have been accepted within mainstream legal education and moral debate, if it is found at all, remains more often than not confined to the ghetto of an optional course in jurisprudence. While leading legal philosophers such as Hart, Finnis, Dworkin - and others - have sought either to clarify, collapse or redraw this boundary between law and morality within jurisprudence, within the remainder of the undergraduate curriculum law students continue to be taught (at least implicitly) that they must maintain this barrier if they wish to acquire the professional knowledge and skills of the 'good lawyer'. ${ }^{23}$ Empirical evidence from

\footnotetext{
${ }^{20}$ See Economides part 3 supra $\mathrm{n} .5$ and Nicolson, supra $\mathrm{n} .6$

${ }^{21}$ See R. Wasserstrom (1984)"Legal Education and the Good Lawyer" Vol. 34 Jor. Legal Education p. 155. Professor Damon in his paper "Recent Research on Good Work and the Development of Young Adults" defines "good work" as work that is both 'excellent' and 'ethical': "To be excellent, the work must be successful according to the standards of the field. To be ethical, the work must be socially responsible and conform to standards such as honesty and integrity."(p.2). See further: A.Colby and W. Damon Some Do care: Contemporary Lives of Moral Commitment New York, Free Press, 1992. Interestingly recent developments in the UK that seek to apply quality assurance standards to legal aid work recognise that 'good' (or competent) work need not necessarily be 'excellent'. Peer review assessments may produce one of five ratings for the performance of legal aid work: (1) Excellence; (2) Competence Plus; (3) Threshold Competence; (4) Below Competence; and (5) Failure in Performance. See Legal Services Commission, Independent Peer Review of Legal Advice and Legal Work. A Consultation Paper (April, 2005) pp.37-39. See further M.Martin, Meaningful Work. Rethinking Professional Ethics Oxford, OUP, 2000.

${ }^{22}$ See A.C. Hutchinson (1998) "Taking it Personally: Legal Ethics and Client Selection" Vol.1 Legal Ethics p.168.

${ }^{23}$ See C. Sampford, (1998) "What's a Lawyer Doing in a Nice Place like this? Lawyers and Ethical Life" Vol.1:1 Legal Ethics p. 35. Note also Cotterrell's comments on the tasks of the standard jurisprudence course: '...in trying to portray contemporary law theoretically in its complexity as experienced by lawyers and others, we need a place for
} 
several jurisdictions confirms that positivistic legal education reinforces cynicism rather than respect for legal values. ${ }^{24}$

There has however been growing unease amongst both academic lawyers and practitioners regarding the cynical attitudes found not only within but also toward the legal profession. Legal Education reviews in several countries have therefore followed the Lord Chancellor's Advisory Committee on Legal Education \& Conduct (ACLEC) in making the case for strengthening the liberal credentials of the law degree by supporting the case for introducing awareness of ethical perspectives, if not mandatory ethical instruction, into mainstream legal education. ${ }^{25}$ The issue today in Japan, as elsewhere, is not so much whether but rather when, how, and how far, this ethical awareness should be introduced in order to supplement and hopefully remedy shortcomings of an overly narrow positivistic legal education. ${ }^{26}$

\section{The Promise of an Ethical Legal Education}

In this section I wish briefly to survey some emerging themes in the ethical education of lawyers. My aim is not to evaluate the approaches that may deliver increased ethical awareness amongst future lawyers but rather to present these as choices that could inform curriculum reform. The practical problem for legal educators is to identify available resources and decide which approach, or combination of approaches, is most likely to fit best with the overall curriculum and support longterm educational goals. ${ }^{27}$ It is perhaps worth noting that the legal profession is not alone in considering how best to introduce ethics into the curriculum. ${ }^{28}$

\section{Formal Approaches}

\footnotetext{
aspiration too. It ought to be part of the task of jurisprudence to test - indeed to breaking point - law's ability to embody reason and principle, to connect with deeply felt moral aspirations, and to produce justice in many different senses of that term.' R. Cotterrell, 'Jurisprudence of Reason and Jurisprudence of Fiat' in P. Birks (ed.) Examining the Law Syllabus. Beyond the Core Oxford, 1993, ch.16, at p.89.

${ }^{24}$ K. Economides, "Cynical legal studies" in Educating for Justice: Social Values and Legal Education eds. J.Cooper and L.Trubek, Dartmouth, 1997, pp. 26-38.

${ }^{25}$ ACLEC, First report on legal education and training, London, 1996 para 1.19-20. Considered in B. Hepple, (1996) 'The renewal of the liberal law degree' Vol. 55Cambridge L.J. 470,484; H.W.Arthurs,'Half a league onward: The report of the Lord Chancellor's Advisory Committee on Legal Education and Conduct' (1997)31 The Law Teacher 1; J. Webb (1988) "Ethics for lawyers or ethics for citizens? New directions for legal education." Vol. $25 \mathrm{~J}$. Law and Society p. 134. See also reviews of legal education in other jurisdictions:: R. MacCrate, Legal Education and Professional Development - An Educational Continuum. Report of the Task Force on Law Schools and the Profession: Narrowing the Gap. Chicago, 1992; D. Pearce, Australian Law Schools: A Discipline Assessment for the Commonwealth Tertiary Commission Australian,1987; W.B.Cotter, Professional Responsibility Instruction in Canada: A Coordinated Curriculum for Legal Education Montreal, 1992; H. Franken, Een eigen richting voor het recht...Eindrapport van de Verkenningscommissie Rechtsgeleerdheid. (A sense of direction...The future of legal research in the Netherlands) Final Report of the Legal Education Review Commission Leiden, 1997) pp. 55-56. For an overview of these education reviews see: A. Boon (2002) "Ethics in Legal Education and Training: Four Reports, Three Jurisdictions and a Prospectus" Vol.5, Legal Ethics pp.34-67

${ }^{26}$ J. Chapman, (2002) "Why teach Legal Ethics to Undergraduates?” Vol.5 Legal Ethics pp. 68-89.

${ }^{27}$ See C. Parker (2004) “ A Critical Morality for Lawyers: Four Approaches to Lawyers Ethics” Vol. 30 Monash University Law Rev. p.49; M. Robertson (2005) "Challenges in the Design of Legal Ethics Learning Systems: An Educational Perspective” Vol.8:2 Legal Ethics pp. 221-239. See also C. Parker and A. Evans, Inside Lawyers' Ethics Cambridge, CUP, 2007.

${ }^{28}$ See S. Illingworth, Approaches to Ethics in Higher Education: Teaching Ethics Across the Curriculum University of Leeds, 2004.
} 
An obvious and common starting point for an understanding of ethical standards of the legal profession is to focus on the rules contained in the professional code of conduct. While the code may, as with a constitution, have an educative side effect its primary purpose is regulatory. It tells members in simple straightforward language what they can and cannot do but does not deal with the complexities of why and how they should act in a professional manner. This may or may not be left to supplementary 'guidance'. At present the professional code forms the basis of formal instruction offered future lawyers, whether these be trainees from within or qualified lawyers transferring from outside a given jurisdiction, and the most common approach aims at ensuring there is an adequate basic knowledge of professional duties in place as well as the capacity to identify relevant rules and issues arising in the context of the lawyer-client relationship. ${ }^{29}$ The vocational courses in many jurisdictions typically focus on the 'micro duties' found in the rules of professional conduct (eg. the retainer, fees, conflict of interest, confidentiality, professional negligence, duties to the court, professional undertakings and money laundering), as well as issues of client care, especially in the lawyer-client relationship, and other obligations arising out of managing accounts and financial services regulation, professional relations with other lawyers and non-lawyers. Increasingly there is also an attempt to move beyond these rules enshrined in the professional code in order to consider 'ethical context'. ${ }^{30}$ Before and after the vocational course, coverage of professional standards remains patchy and inconsistent, and during these courses the approach commonly adopted appears to be dogmatic and uncritical. ${ }^{31}$ Lawyers are taught that they must comply with, rather than question or criticise, their code. As Nicolson has pointed out, professional codes are both important yet insufficient: and they have an ambivalent influence in that they may either nurture or detract from the development of the lawyer's professional moral character. ${ }^{32}$ In the future we may therefore require a different kind of 'contextual' code if we are to take seriously the task of making lawyers 'moral'. ${ }^{33}$ While the professional code should not be ignored it is also clear that, in isolation, it offers an inadequate foundation for legal professionalism. There is a further need for some kind of context - whether derived from theory, practice or the humanities - in order to put ethical flesh on legal bones and expose the latent dilemmas that only really become apparent once it is recognised that rules of conduct contained in the code often collide. At this point external guidance drawing upon human and legal experience is required to assist the process of ethical decision-making.

\section{Theoretical Approaches}

If the code provides an obvious starting point for studying professional responsibility another point worth making is that, as with theory itself, ethics cannot be avoided and the only real choice left the educator is to decide whether to make the ethical values and theory latent in the curriculum explicit. ${ }^{34}$ University legal education provides an ideal opportunity to examine underlying theoretical perspectives on professional responsibility and it is now widely appreciated that inculcating

\footnotetext{
${ }^{29}$ At present about a quarter of all new admissions into the solicitors profession are transfers from overseas, the Bar, FILEX, justices clerks or other routes.

${ }^{30}$ See S. Bullock, Ethics Education Forum: Report into Ethics Training in Other Jurisdictions, Law Society, London, 2004.

${ }^{31}$ See eg. W. H. Simon (1991) 'The trouble with legal ethics' Jor. of Legal Education 65. See also Simon's study analysing these problems and proposing solutions: The Practice of Justice. A Theory of Lawyers' Ethics Cambridge, Ma.,1998) reviewed by T. Campbell (1998) "Moral Autonomy for Lawyers: A Review of William H Simon" Vol. 1 Legal Ethics p. 201.

${ }^{32}$ D. Nicolson, supra n. 6.

${ }^{33}$ Ibid.at pp. 620-624.

${ }^{34}$ C. Menkel-Meadow (1991) "Can a law teacher avoid teaching legal ethics?" Vol. 41 Jor.Legal Education at p.3.
} 
professionalism need not be left entirely to the vocational courses and apprenticeship. As Sir Bob Hepple observes:

The teaching of professional ethics and conduct cannot simply be left to vocational courses or in-service training. Students have to imbibe a sense of the obligations which lawyers owe not simply to their own clients or employers but to society as a whole: in maintaining and improving fundamental democratic values, including the protection of human rights and the defense of individuals against the abuse of public and private power, as well as providing legal services for disadvantaged sections of the population ${ }^{35}$

Ethical theory - whether Kantian, consequentialist, aretaic, postmodern or feminist in outlook - can provide a valuable analytical tool with which to understand and dissect ethical dilemmas within a philosophical context. ${ }^{36}$ On the other hand, theory alone probably will not produce definitive answers to practical problems confronting lawyers in practice and, by opening up endless further choices to consider, could simply confuse and delay practical decision-making. Furthermore, there is no conclusive empirical evidence to suggest that ethics education actually produces 'good lawyers' ${ }^{37}$

\section{Clinical Approaches}

Although not part of mainstream legal education in the United Kingdom, clinical legal education clearly has considerable potential to offer law students the opportunity to observe, practice and reflect on ethics in action. ${ }^{38}$ This approach concentrates on the acquisition of legal skill through the practical application of legal knowledge. Experience from the United States is on the whole encouraging and it would appear that exposure to clinical experience may have a profound and lasting impact in terms of establishing not only key skills but also core legal values and ethical commitment amongst future members of the legal profession. ${ }^{39}$ Pro bono initiatives are therefore important not only because they may provide legal services to those who might otherwise not receive them; they also offer valuable opportunities to young lawyers to acquire professional skills and a sense of responsibility that will stay with them for the rest of their careers. This could be an important counterweight to the cynicism that pervades much of modern legal education. ${ }^{40}$ One

\footnotetext{
${ }^{35}$ Hepple, supra $n$. 25. See also R. Cranston, How Law Works. The Machinery and Impact of Civil Justice Oxford, OUP, 2006, pp.207-208. But see H.W. Arthurs "Why Canadian Law Schools Do Not Teach Legal Ethics" in Economides supra n.5 chap.6.

${ }^{36}$ See, eg. C. Gill "Law and Ethics in Classical Thought" supra n.5. chap.1. L.P. Pojman, Ethical Theory: Classical and Contemporary Readings, Wadsworth Publishing, $4^{\text {th }}$ edn., 2001. D. Nicolson and J.Webb, Professional Legal Ethics: Critical Interrogations Oxford, OUP, 1999, Chap.2.

${ }^{37}$ See Arthurs supra n. 35. M. Robertson and K. Tranter (2007) "Grounding legal ethics learning in social scientific studies of lawyers at work" Legal Ethics (forthcoming).

${ }^{38}$ See J. Webb (1996) "Inventing the Good: A Prospectus for Clinical Education and the Teaching of Legal Ethics in England "Vol. 30 The Law Teacher, p. 270; D.A. Schon, (1995) "Educating the Reflective Practitioner" Vol. 2 Clinical Law Rev. p. 231; C. Maughan and J. Webb Lawyering Skills and the Legal Process, Cambridge, CUP, $2^{\text {nd }}$ edn, 2005, chap.6; J. Webb (1998) "Ethics for Lawyers or Ethics for Citizens? New Directions for Legal Education" Vol.25:1 Journal of Law and Society pp. 134-150.

${ }^{39}$ See MacCrate supra n.24; E.B. Spaeth, Jr.; J. G. Perry; P. B. Wachs (1995) "Teaching Legal Ethics: Exploring the Continuum" Vol. 58 (3/4) Law and Contemporary Problems, pp. 153-172; But compare: R Condlin, The Moral Failure of Clinical Legal Education Center for Philosophy and Public Policy, University of Maryland, 1981.

${ }^{40}$ See K. Economides, supra n.24.
} 
recent development is not to use live clients but rather to create simulated virtual learning environments through which law students can experience the lawyer-client and other relationships. ${ }^{41}$

\section{Humanistic Approaches}

Another approach to communicating the nature and essence of professional ethics to future lawyers is draw upon literary sources and other representations of legal work found in popular culture such as film and television. ${ }^{42}$ The broad aim here is to use narrative as a means of developing ethical judgment. Law students are expected to analyse stories as case studies in which they can recognize and resolve ethical dilemmas found in legal practice. Literature and film may thus provide a kind of laboratory in which to examine professional responsibility. ${ }^{43}$ These approaches are valuable in that they can expose tensions between professional and personal morality but, on the other hand, there is a risk of severe distortion of the reality of the legal process in the interest of providing popular entertainment. These approaches can often be used in conjunction with, or as supplements to, the other formal, theoretical and clinical approaches described above.

\section{Legal Education Reform in Japan}

The Justice System Reform Council of Japan initiated something of a 'quiet revolution' when it recommended in 2001 a fundamental reform of Japanese legal education that by April 2004 had resulted in the establishment of 68 new graduate-level law schools modelled on those found in the United States. ${ }^{4}$ These reforms could create a far more diverse legal profession and should enhance access to justice for Japanese citizens. But these reforms will also impact on the content and delivery of legal education: as from April 2007 these 68 new law schools will be free to experiment with innovative curriculum reform that previously was not possible, while some institutions have already been piloting simulated experiential programmes that could nurture a range of lawyering skills including ethical awareness. ${ }^{45}$ A select number of these new law schools are already closely monitoring foreign experience in order to identify promising educational practices found in western law schools that might be imported in order to raise ethical, educational and practice standards in Japan. ${ }^{46}$ Questions arise as to whether these foreign imports are likely to take root in Japanese legal culture and whether this culture has anything to offer those interested in reforming legal education in

\footnotetext{
${ }^{41}$ Supra n.2.

${ }^{42}$ See P. Brooks and P. Gewirtz Law's Stories: Narrative and Rhetoric in the Law Yale Univ. Press, New Haven \& London, 1996.

${ }^{43}$ See, eg, T. Dare's discussion of "To Kill a Mockingbird" in Economides supra, n.5 chap.3. See also: C. MenkelMeadow (2000) "Forward Telling Stories in School: Using Case Studies and Stories to Teach Legal Ethics" Vol.69 Fordham Law Rev.p. 787; R.C. Cramton and S.P. Koniak (1996) "Rule, Story, and Commitment in the Teaching of Legal Ethics" Vol.38 William \& Mary Law Rev.p. 145; L.G.Webster, (1991) "Telling Stories: The Spoken Narrative Tradition in Criminal Defense Discourse" Vol. 42 Mercer Law Rev. p.553.

${ }^{44}$ There are 92 universities with an undergraduate law faculty and approximately 50,000 law-major undergraduate students in Japan. Among those 92 universities, 71 universities and one brand new university applied for opening a law school in 2004. Consequently, 68 law schools were approved and 4 failed to obtain approval. Nine selected universities all applied but one failed.

${ }^{45}$ S. Brown, (2005) “A True Meeting of Minds: A Conference Report from Japan”, Vol.8:1 Legal Ethics, pp. 12-15.

${ }^{46}$ Japanese law schools have been visiting a number of foreign law schools in the US, Australia and the UK to observe developments relating to simulated learning and clinical legal practice. In February 2007 UK law schools in Glasgow, Northumbria, Warwick and London were visited by a team from the Kwansei Gakuin University Law School in Osaka.
} 
the West. ${ }^{47}$ For example, one US law teacher teaching in Hokkaido reports a number of obstacles in bringing western-style ethics to the Japanese, whether through simulations or clinical experience:

During my stay in Japan, I discovered that discussions of ethical education with my colleagues at Hokkaido University invariably caused concern. Perhaps my choice of words, more than the concept of ethical education, generated much anxiety. For many of my colleagues, a frightening legacy remains from the educational indoctrination methods used in Imperial Japan, particularly those relating to the 1890 Imperial Rescript on Education. For others, there appears to be a reluctance to allow faculty members to paternalistically impose their own moral views on university students who have already completed their development into adults. However, such fears reflect a misunderstanding of the nature of ethical education suggested here. The goal is not imposition of a dogmatic pedagogy of what is right and wrong. Rather, the first purpose is to introduce students to the inevitability of ethical quandaries arising in a conscientious career. Secondly, we should help them understand their own conscience of what might be right and wrong in such situations. Finally, we must give them the intellectual tools necessary for coping with the challenges that they may face on those occasions. ${ }^{48}$

These goals are worth noting for very similar challenges confront those wishing to develop ethical awareness here in the West that should also include lawyers' public and social duties:

Graduates of Japanese law schools are destined to become Japan's government, business, and social leaders. How those persons will weigh the moral challenges of their time will create the base for the next generation's social order. The educational task is not to instruct about rules, but to foster a mature awareness for the challenges that may arise in our students' futures. For example, we can discuss what one might do if directed by a superior to act illegally, such as to give a bribe. We might ask whether an act that is not clearly illegal can still be wrong, or what courses of action are available if one is not doing a questionable act, but instead discovers illegal or wrong actions being done by one's colleagues or superiors? And, what might be the consequences of pursuing the various available options at that time? Ideally, students should come to understand their own values about these questions and that others may not view the world the same way. Then, if issues such as these arise for graduates in the future, they will be better prepared to assess the circumstances and choose a socially constructive path. ${ }^{49}$

This international experience raises two connected issues of fundamental importance for the future of legal education, both in Japan and the West. How should legal educators: (1) teach ethics without being overly paternalistic, yet at the same time remain sensitive to wider professional and national cultures; and (2) assist the development of individual

\footnotetext{
${ }^{47}$ On the problems of legal transplants, see generally, D. Nelken and J. Feest (eds), Adapting Legal Cultures Oxford, Hart, 2001; D. Nelken (2003) "Legal Transplants and Beyond: Of Disciplines and Metaphors" in Comparative Law for the 21st century, eds A. Harding and E. Orucu, Hague, Kluwer, 2003.

48 M..Levin, "Legal Education for the Next Generation: Ideas from America" http://www.cmmi.gr.jp/effort/pdf/levin.pdf. pp.14-15.

${ }^{49}$ Ibid.p.15. See also M. A. Levin (2005) “Japan's New Law Schools: Elite, Cautious, Regional, and Idealist” Vol. 62 Japanese Journal of Law and Society p. 139.
} 
values and awareness of contrasting perspectives emanating from the 'Other'? In my view law teachers need to respond by remaining constantly alert to the danger of promoting their own subjective beliefs at the expense of core professional values, whilst allowing students sufficient autonomy in order that they are free to explore their own independent understanding of professional values. ${ }^{50}$ In Japan, given the legal system's positivistic Germanic roots and the dirigiste approach that still dominates the new post-baccalaureate law schools, far greater caution can be expected amongst law teachers who may well fear experimenting with normative values when teaching professional responsibility to adults. It therefore seems safe to predict that in Japan there will be a reluctance to engage with more advanced methods advocated by some leading law teachers in the West. ${ }^{51}$ But while significant cultural differences amongst lawyers in Japan and the West may well persist, we should not forget that there is also much that binds lawyers together wherever they happen to practice. Instead of concentrating on local and cultural differences, which inevitably will be emphasised in skills and vocational training, and apprenticeship, academic teachers might focus first on the universal values common to all lawyers that are enshrined in formal codes. ${ }^{52}$ More needs to be done to communicate the nature and significance of core legal values. Thereafter, it should be possible to supplement these sources by introducing a variety of perspectives drawing upon theoretical, clinical and humanistic approaches outlined earlier that might well be grounded in local legal cultures. At the same time it would be well to lower expectations about how far it is possible to influence the value systems of law students for the available empirical evidence suggests that law schools have only a limited impact wherever they venture beyond teaching rules. ${ }^{53}$ Nevertheless, it does matter that, as educators, we accept responsibility for our students and do all we can to point out to the next generation of lawyers wherewe think the right path to justice lies. ${ }^{54}$

\footnotetext{
${ }^{50}$ See K.Economides, supra n.24 at p.33-34.

${ }^{51}$ Eg,. D. L. Rhode, Professional Responsibility: Ethics by The Pervasive Method 2d. ed., 1995; E. W. Myers (1997) "Teaching Good and Teaching Well: Integrating Values With Theory and Practice "Vol. 47 Jor. of Legal Education, p. 401; D. N. Frenkel (2001) "On Trying to Teach Judgment" Vol. 12 Legal Education Rev., p.19; D.Luban and M. Milleman, (1995) "Good Judgment: Ethics Teaching in Dark Times" Vol. 9 Georgetown. Jor. Legal Ethics, p.31.

${ }^{52}$ See A. Boon and J.Flood (1999) "Globalization of Professional Ethics? The Significance of Lawyers' International Codes of Conduct", Vol.2:1 Legal Ethics, pp. 29-57; H.W.Arthurs (1999) "A Global Code of Legal Ethics for the Transnational Legal Field", Vol.2:1 Legal Ethics, pp. 59-69.

${ }^{53}$ See n.37 supra and A. Evans and J. Palermo (2002) "Australian Law Students' Perceptions of their Values: Interim Results in the First Year-2001 - of a Three Year Empirical Assessment" Vol.5 Legal Ethics, pp.103; A. Evans and J. Palermo (2005) “Zero Impact: Are Lawyers' Values Affected by Law School?” Vol. 8 Legal Ethics, p. 240.

${ }^{54}$ K.Economides (2006) “The Road to Justice Revisited: Current Trends in Professional Legal Ethics”, Vol. 27:1 Recht der Werkelijkheid , pp.3-18.
} 